\title{
PENERAPAN AKUNTANSI PERSEDIAAN BARANG DAGANG PADA UD. MUDA-MUDI TOLITOLI
}

\author{
Kenny Regina Karongkong ${ }^{1}$, Ventje Ilat $^{2}$, Victorina Z. Tirayoh ${ }^{3}$ \\ 1,2,3 Jurusan Akuntansi, Fakultas Ekonomi dan Bisnis, Universitas Sam Ratulangi, Jl. Kampus Bahu, Manado, \\ 95115, Indonesia \\ E-mail : kennyrk@yahoo.com
}

\begin{abstract}
In trading company, inventory is a valuable resource as it become the larger asset than current asset. It because the primary income of the company coming from selling goods from inventory. Therefore, accounting management for the inventory is important to avoid fraud. The data for This paper is provided by a distributor company that provide a basic needs for the consumer to implement an accountable inventory management. The Object of this paper is a company name UD. Muda-Mudi Tolitoli. This paper is using a DeskriptifKualiatif method. This Paper conclude that UD. Muda-Mudi has implemented accountable based for their inventory management but still need an improvement about providing a division workload for entry and saving goods and income.
\end{abstract}

Keyword : inventory, deskriptif kualitatif

\section{PENDAHULUAN}

Perkembangan dunia usaha mengalami persaingan yang cukup ketat, baik dalam bidang industri barang maupun jasa. Persaingan tersebut salah satunya disebabkan oleh kemajuan teknologi yang berkembang pesat, munculnya pesaing-pesaing baru yang berpotensi dalam mengembangkan produk-produk yang beraneka ragam dan berkualitas. Oleh karena itu perusahaan terus dituntut untuk dapat meningkatkan seluruh aktivitasnya agar mampu bersaing dalam mempertahankan hidup perusahaan, sehingga tujuan perusahaan akan tercapai. Setiap perusahaan, khususnya perusahaan dagang selalu membutuhkan persediaan. Persediaan dapat diartikan sebagai aktiva yang tersedia untuk dijual dalam kegiatan usaha normal perusahaan. Selain itu persediaan dapat juga diartikan sebagai aktiva yang digunakan dalam proses produksi. Persediaan memegang peran penting dalam perusahaan, terutama perusahaan manufaktur.

Perusahaan manufaktur persediaan dibagi menjadi empat jenis persediaan, yaitu persediaan bahan baku, persediaan bahan penolong, persediaan dalam proses dan persediaan barang jadi. Dalam perusahaan dagang, persediaan hanya terdiri dari satu golongan saja yaitu persediaan barang dagangan yang merupakan barang yang dibeli untuk tujuan dijual kembali. Istilah persediaan atau inventory umumnya ditujukan pada barang yang dimiliki perusahaan untuk dijual dalam operasi bisnis normal atau dikonsumsi dalam memproduksi barang yang akan dijual. Deskripsi dan pengukuran persediaan biasanya membutuhkan kecermatan karena investasi dalam persediaan merupakan aktiva lancar paling besar dari perusahaan dagang dan manufaktur. Perusahaan dagang dapat didefinisikn sebagai organisasi yang melakukan kegiatan usaha dengan membeli barang dari pihak atau perusahaan lain kemudian menjualnya kembali kepada masyarakat. Setiap perusahaan pasti bertujuan untuk menghasilkan laba optimal agar dapat mempertahankan kelangsungan hidupnya, memajukan serta mengembangan usahanya ketingkat yang lebih tinggi. 
Penerapan akuntansi persediaan sangat penting dan bagus dalam kegiatan perekonomian. Pada dasarnya akuntansi secara sederhana adalah proses mencatat transaksi keuangan untuk kemudian disajikan dalam laporan keuangan. Maka dalam pengertiannya terkandung tujuan dari adanya akuntansi, yaitu menyajikan laporan keuangan. Dengan akuntansi kita bisa mengetahui bagaimana perkembangan perusahaan, bagaimana keadaan persediaan dan langkah apa yang akan kita lakukan untuk memajukan perusahaan dan kelangsungan perusahaan.

UD. Muda-Mudi Tolitoli adalah sebuah perusahaan yang bergerak di bagian penjualan dan distributor berbagai jenis perlengkapan dan pakaian olahraga. Karena cukup banyak produk dan mobilitas keluar masuk barang sehingga dikhawatirkan akan terjadi kehilangan atau pencurian stock barang, akibatnya diperlukan penerapan akuntansi persediaan yang baik agar tidak terjadi penyelewengan dalam menjalankan tugas, UD. MudaMudi Toli-Toli secara konvensional belum dapat menentukan nilai persediaan.

\section{TINJAUAN PUSTAKA}

\subsection{Konsep Akuntansi}

Akuntansi adalah suatu kegiatan yang berhubungan dengan jasa, yaitu jasa dalam menyediakan informasi transaksi dalam perusahaan, fungsi akuntansi yaitu juga untuk menyediakan informasi keuangan dalam perusahaan, akuntansi juga menyediakan data kuantitatif yang bersifat dari kesatuan ekonomi yang digunakan dalam mengambil keputusan dalam memilih langkah yang tepat dalam pengambilan keputusan akhir perusahaan. Akuntansi juga bisa dikatakan sebagai proses pencatatan, penggolonggan, juga peringkasan dan penyajian secara sistematis dari seluruh transaksi keuangan suatu perusahaan, juga sebagai penafsiran terhadap hasilnya.. Tujuan akuntansi yaitu menyajikan informasi tentang ekonomi dari kesatuan ekonomi untuk pihak-pihak berkepentingan baik ekstern maupun intern dalam perusahaan.

\subsection{Konsep Akuntansi Keuangan}

Akuntansi keuangan adalah merupakan salah satu bidang akuntansi yang berhubungan dalam menyediakan informasi akuntansi yang berhubungan dengan penyajian laporan keuangan bagi pemakai atau pengambil keputusan yang ada di luar organisasi atau pihak eksternal, seperti kreditur, insvestor, dan lain lain. Informasi keuangan di hasilkan berdasarkan Prinsip Akuntansi yang Berlaku Umum (PABU) atau Generally Accepted Accounting Principles (GAAP). Akuntansi keuangan berhubungan dengan masalah pencatatan transaksi untuk suatu perusahaan atau organisasi dan penyusunan berbagai laporan berkala dari hasil pencatatan. Akuntansi Keuangan merupakan salah satu dari akuntansi yang berhubungan dengan penyajian informasi pelaporan keuangan perusahaan kepada pihak eksternal berupa laporan laba rugi, neraca, Perubahan Modal dan Arus Kas juga pencatatan atas laporan keuangan yang diserahkan kepada kepada pemegang saham, kreditor atau investor khususnya tentang profitabilitas dan kredibilitas perusahaan, kepada supplier, dan pemerintah. Laporan keuangan yang disajikan hendaknya harus sesuai dengan prinsip akuntansi yang berlaku umum atau sesuai dengan Pernyataan Standar Akuntansi Keuangan (PSAK) tentang petunjuk dan prosedur akuntansi yang berisi tentang standar-standar pencatatan, standar penyusunan, dan juga penyajian laporan keuangan yang mengacu pada beberapa teori-teori tentang penafsiran dan penalaran yang mendalam oleh suatu lembaga yang kita kenal yang dinamakan Ikatan Akuntan Indonesia (IAI).

\subsection{Persediaan}

Persediaan merupakan salah satu istilah yang digunakan untuk menunjukan barangbarang yang dimiliki oleh suatu perusahaan yang tergantung pada jenis usaha perusahaan masing-masing. Peresediaan yaitu barang-barang yang disimpan untuk digunakan atau dijual pada masa atau periode yang akan datang. 


\subsubsection{Pengertian Persediaan}

Persediaan merupakan barang yang disimpan untuk digunakan nanti atau dijual pada masa masa tertentu tergantung pada permintaan yang ada atau akan dijual pada periode yang akan datang. Persediaan terdiri dari persediaan barang baku, persediaan barang setengah proses produksi, sedangkan persediaan jadi atau barang dagangan disimpan sebelum dijual atau dipasarkan.

\subsubsection{Tujuan dan Fungsi Persediaan}

\subsubsection{Tujuan Persediaan}

Pada prinsipnya maksud persediaan adalah untuk memudahkan dan melancarkan proses produksi suatu perusahaan dalam memenuhi kebutuhan konsumennya. Karena membutuhkan waktu menyelesaikan operasi dan untuk memindahkan produk dari suatu proses ke proses yang lain yang disebut sebagai persediaan dalam proses dan Untuk memungkinkan suatu unit atau bagian membuat jadwal operasinya secara bebas, tidak tergantung dari lainnya. Adapun tujuan persediaan adalah sebagai berikut :

1. Menghilangkan resiko keterlambatan datangnya barang/bahan yang dibutuhkan perusahaan

2. Menghilangkan resiko dari materi yang dipesan berkualitas tidak baik sehingga harus dikembalikan;

3. sebagai salah satu alternatif dalam mengantisipasi bahan yang dihasilkan atau diproduksi tergantung pada musim atau barang yang dihasilkan musiman sehingga dapat digunakan bila bahan itu tidak ada dalam pasaran;

4. Mempertahankan stabilitas operasi perusahaan atau menjamin kelancaran arus produksi;

5. Mencapai penggunaan mesin yang optimal;

6. Memberikan pelayanan kepada langganan dengan sebaik-baiknya dengan memberikan jaminan tersedianya

barang jadi

7. Membuat pengadaan atau produksi tidak perlu sesuai dengan penggunaan atau penjualannya.

\subsubsection{Fungsi Persediaan}

Fungsi Persediaan yaitu mengefektifkan sistem persediaan bahan, efisiensi operasiona perusahaan dapat ditingkatkan melalui fungsi persediaan dengan mengefektifkan :

1. Fungsi Indenpendensi. Persediaan memiliki fungsi agar perusahaan dapat melakukan proses produksi meski supplier tidak dapat menyanggupi jumlah dan waktu pemesanan barang yang dilakukan perusahaan dengan cepat.

2. Fungsi Ekonomis. Persediaan memiliki fungsi agar perusahaan dapat menggunakan seluruh sumber daya yang dimiliki oleh perusahaan dalam menjalankan kegiatan operasional perusahaan.

3. Fungsi Antisipasi. Persediaan memiliki fungsi agar perusahaan dapat melakukan antisipasi pada perubahahan permintaan konsumen. Persediaan merupakan sebuah istilah yang menunjukkan segala sesuatu dari sumber daya yang ada dalam suatu proses yang bertujuan untuk mengantisipasi terhadap segala kemungkinan yang terjadi baik karena adanya permintaan ataupun ada masalah lain.

\subsubsection{Jenis-jenis Persediaan}

Jenis-jenis persediaan akan berbeda sesuai dengan bidang atau kegiatan normal usaha perusahaan tersebut. Berdasarkan bidang usaha perusahaan dapat berbentuk perusahaan industri (manufacture), perusahaan dagang maupun perusahaan jasa. Untuk perusahaan industri maka jenis persediaan yang dimiliki adalah persediaan bahan baku, barang dalam proses, persediaan barang jadi, serta bahan pembantu yang akan digunakan dalam proses produksi. Dan perusahaan dagang maka persediaannya hanya satu yaitu barang dagang. 


\subsubsection{Sistem Pencatatan Persediaan}

Dalam pelaporan, masalah akuntansi persediaan dapat diselenggarakan dengan menggunakan metode pencatatan dan metode penilaian. Metode pencatatan berkaitan dengan prosedur perekaman kuantitas dan mutasi masuk dan keluar, serta saldo persediaan. Sementara metode penilaian berkaitan dengan prosedur alokasi harga perolehan persediaan sebagai nilai persediaan akhir dan pembebanannya sebagai harga pokok penjualan. Dua metode pencatatan persediaan yang lazim digunakan adalah (a) metode fisik, dan (b) metode perpetual.

\subsubsection{Metode Penilaian Persediaan}

Ada beberapa macam metode penilaian persediaan yang umum digunakan, yaitu : Alokasi Harga Pokok, Masuk Pertama Keluar Pertama (FIFO), Masuk Terakhir Keluar Pertama (LIFO), dan Metode Rata-rata (Average).

1) Alokasi Harga.

Pada metode ini, biaya dapat dialokasikan kebarang yang terjual selama periode berjalan dan ke barang yang ada di tanagn pada akhir periode berdasarkan biaya aktual dari unit tersebut. Metode ini diperlukan untuk mengidentifikasi biaya historis dari unit persediaan. Dengan mengidentifikasi khusus, arus biaya yang di catat disesuaikan dengan arus fisik barang.

2) Metode Masuk Pertama Keluar Pertama

Metode masuk pertama keluar pertama atau First In First Out. Dibuat dengan asumsi bahwa barang yang pertama dibeli, barang itu pula yang terlebih dahulu dikeluarkan jika terjadi penjualan. Tetapi dalam akuntansi persediaan, yang diperhitungakan sebagai unsur masukdan keluar tersebut buka fisik tetapi nilai perolehan persediaannya. Untuk menilai barang yang paling terdahulu pembeliannya, dari sekian banyak yang masih ada digudang. Nilai persediaan barang yang masih ada digudang diambil dari harga beli barang yang terakhir dibeli. Metode FIFO dapat dianggap sebagai sebuah pendekatan logis dan realistis terhadap arus biaya terhadap penggunaan metode identifikasi khusus adalah tidak memungkinkan atau tidak praktis. FIFO mengasumsikan bahwa arus biaya yang mendekati pararel yang mengdekasi arus fisik dari barang yang terjual. Beban yang dikenakan pada nilai melekat pada barangyang terjual. FIFO memberikan kesempatan kecil untuk memanipulasi keuntungan karena pembebanan biaya ditentukan oleh urutan terjadinya biaya. Selain itu, didalam FIFO unit yang tersisa pada persediaan akhir adalah unit yang paling akhir dibeli, sehingga biaya yang dilaporkan akan mendekati atau sama dengan biaya penggantian di akhir periode.

3) Metode Masuk Terakhir Keluar Pertama

Metode Masuk Terakhir Keluar Pertama atau Last In First Out. Metode ini merupakan kebalikan dari metode FIFO. Dalam metode ini nilai persediaan akhir diambil dari harga barang yang lebih dahulu dibeli. Nilai harga pokok penjualan diambil dari hasil perhitungan atau akumulasi harga beli barang yang terakhir dibeli. Seperti halnya metode FIFO, metode ini juga dapat dibuat dalam metode fisik dan metode perpetual.

4) Metode Biaya Rata-rata

Metode ini membebankan biaya rata-rata yang sama ke setiap unit. Metode biaya rata-rata, nilai persediaan diperhitungankan sama untuk semua iem persediaan sepanjang periode pencatatan. Nilai per uni persediaan dapat dihitung dengan menjumlahkan semua nilai perolehan persediaan awal dan pembelian pada periode berjalan kemudian di bagi dengan total volumenya. Hasil pembagiannya merupakan nilai rata-rata persediaan per unit.

\subsubsection{Biaya-biaya Persediaan}

Berikut merupakan unsur biaya yang terdapat pada persediaan. Biaya-biaya terbagi atas tiga bagian pokok, adalah sebagai berikut: 
1. Biaya Pemesanan (ordering cost/procurement cost) adalah biaya yang dikeluarkan sehubungan dengan kegiatan pemesanan barang yang dimulai dari penempatan pemesanan hingga tersedianya barang tersebut. Biaya ini mencakup biaya-biaya antara lain:

a. Biaya administrasi dan penempatan order

b. Biaya pemilihan vendor,

c. Biaya pengangkutan dan bongkar muat,

d. Biaya penerimaan dan pemeriksaan barang.

2. Biaya Penyimpanan (holding cost atau carrying cost) adalah biaya yang dikeluarkan berkaitan dengan diadakannya persediaan barang. Dan biaya penyimpanan ini dinyatakan dalam 2 bentuk yakni sebagai persentase dari nilai rata-rata persediaan ter tahun dan dalam bentuk rupiah per tahun per unit barang. Yang termasuk dalam biaya ini adalah:

a. Biaya sewa gudang,

b. Biaya administrasi pergudangan,

c. Biaya gaji pelaksana gudang,

d. Biaya listrik, air dan telepon.

e. Biaya modal yang ditanam dalam persediaan,

f. Biaya asuransi,

g. Biaya kerusakan / kehilangan dan penyusutan persediaan.

3. Biaya Kekurangan Persediaan (shortage cost/stock cost) adalah biaya yang timbul karena tidak tersedianya barang persediaan pada waktu diperlukan. Yang termasuk dalam biaya ini adalah antara lain biaya kesempatan yang yang timbul karena terhentinya proses produksi, biaya adminitrasi tambahan, biaya kehilangan pelanggan.

\section{METODE PENELITIAN}

\subsection{Jenis Penelitian}

Penelitian ini termasuk jenis deskriptif Kualitatif. Menurut Erlina (2007:64), "Penelitian deskriptif adalah penelitian terhadap fenomena atau populasi tertentu yang diperoleh oleh peneliti dari subjek beberapa individu, organisasi, industri atau perspektif lain".

\subsection{Tempat dan Waktu Penelitian}

Penelitian ini dilakukan pada UD. Muda-Mudi Tolitoli yang beralamat di Jl. Hi. Hasan No. 172, Kelurahan Baru, Kecamatan Baolan, Kota Tolitoli, Sulawesi Tengah. Adapun penelitian dilaksanakan selama 3 bulan.

\subsection{Prosedur Penelitian}

Penelitian ini menggunakan tahap penelitian yang berhubungan dengan masalah yang diteliti. Tahapan-tahapan tersebut sebagai berikut :

1. Melakukan observasi pada objek penelitian.

2. Mengidentifikasi permasalahan yang signifikan untuk dipecahkan melalui metode deskriptif.

3. Merumuskan permasalahan yang jelas dan menemukan tujuan serta manfaat penelitian

\subsection{Metode Pengumpulan Data}

\subsubsection{Jenis Data}

Data ialah bahan mentah yang perlu diolah sehingga menghasilkan informasi atau keterangan, baik kualitatif maupun kuantitatif yang menunjukkan fakta sehingga dapat memberi manfaat bagi peneliti atau memberi gambaran kepada peneliti tentang kondisi atau suatu keadaan. Jenis data dibagi menjadi dua, yaitu :

1. Data Kualitatif adalah data yang berhubungan dengan kategorisasi, karakteristik berwujud pernyataan atau berupa kata-kata. Data ini biasanya didapat dari wawancara yang bersifat subjektif. 
2. Data Kuantitatif yaitu data yang berwujud angka-angka atau bilangan.

Dalam penelitian ini, jenis data yang digunakan adalah data kualitatif, dimana data tersebut berupa gambaran umum UD. Muda-Mudi Tolitoli, dan struktur organisasi.

\subsubsection{Sumber Data}

Sumber data adalah segala sesuatu yang dapat memberikan informasi mengenai data. Adapun data yang penulis peroleh melalui :

a. Data Primer adalah data yang diperoleh secara langsung dengan mengadakan penelitian terhadap objek yang di teliti untuk memperoleh data primer, dengan melakukan wawancara kepada pihak yang bersangkutan.

b. Data Sekunder adalah data yang diperoleh secara tidak langsung melalui media perantara (Melihat penelitian yang sudah pernah dilakukan sebelumnya), menggunakan metode tinjauan kepustakaan (library reserch) membaca buku-buku yang berkaitan dengan masalah yang ingin diteliti, dan dilihat dari mengakses website dan situs-situs yang di berkaitan.

\subsubsection{Teknik Pengumpulan Data}

Untuk memperoleh data dan bahan yang diperlukan dalam penelitian ini penulis menggunakan alat pengumpulan data sebagai berikut :

1. Survei Pendahuluan yaitu kegiatan langkah awal untuk mencari judul penelitian skripsi dan masalah yang bisa di angkat menjadi bahan penelitian dengan membaca Jurnal Riset Akuntansi Indonesia (JRAI), Seminar Nasional Akuntansi (SNA) maupun karya tulis ilmiah lainnya. Setelah menentukan judul penelitian skripsi dan masalah yang akan diangkat dalam penelitian melalui jurnal, maka langkah selanjutnya adalah mencari objek penelitian yang tepat dan sesuai judul penelitian skripsi. Dalam hal ini penulis memilih UD. Muda-Mudi Tolitoli sebagai objek penelitian dan selanjutnya mengajukan surat permohonan izin kepada pimpinan perusahaan.

2. Survey lapangan adalah pengumpulan data dengan cara penelitian langsung pada perusahaan yang menjadi objek penelitian dengan cara berikut ini :

a. Teknik Dokumentasi; pengumpulan data dan informasi melalui buku-buku, jurnal, internet, dan dengan melakukan penelitian terhadap dokumen-dokumen dan laporanlaporan perusahaan yang berkaitan dengan penelitian, seperti company profil.

b. Teknik Wawancara; penelitian dengan cara tanya jawab secara langsung dengan pihak-pihak yang bersangkutan dengan masalah yang diteliti, sehingga penulis dapat memperoleh keterangan dan pendapat mengenai pengendalian intern persediaan tersebut. Wawancara yang dilakukan adalah wawancara informal (wawancara lisan) dengan cara tanya jawab secara langsung terhadap pihak-pihak yang bersangkutan, seperti bagian akuntansi dan keuangan.

\subsubsection{Metode Analisis Data}

Metode analisis yang digunakan dalam penelitian ini adalah metode analisis deskriptif, yaitu suatu teknik untuk mengungkapkan dan memaparkan pendapat dari responden berdasarkan jawaban dari instrumen penelitian yang telah diajukan oleh peneliti. Dari data yang telah terkumpul kemudian dilakukan analisis data secara deskriptif yaitu dengan cara memaparkan secara objektif dan sistematis situasi yang ada dilapangan. Metode deskriptif adalah penelitian yang dilakukan untuk mengetahui keberadaan variabel mandiri (baik satu variabel atau lebih dari satu variabel) tanpa membuat perbandingan dan mencari hubungan variabel itu dengan variabel yang lain. 


\section{HASIL ANALISIS DAN PEMBAHASAN \\ 4.1. Hasil analisis \\ Tujuan Persediaan}

Penerapan Akuntansi Persediaan atas barang dagang pada UD. Muda-mudi Tolitoli dengan beberapa tujuan persediaan diantaranya :

1. Menghilangkan pengaruh ketidakpastian,

2. Memberi waktu luang untuk pengelolaan produkasi dan pembelian,

3. Untuk mengantisipasi bila terjadi perubahan pada permintaan dan penawaran,

4. Mengurangi resiko keterlambatan pengiriman bahan,

5. Menyesuaikan dengan jadwal produksi,

6. Menghilangkan/mengurangi resio kenaikan harga,

7. Menjaga atau mengantisipasi persediaan bahan yang dihasilkan secara musiman,

8. Mengantisipasi permintaan yang dapat diramalkan,

9. Mendapatkan keuntungan dari quantity discount, dan

10. Komitmen terhadap pelanggan. (Sunyoto,2012;15).

\section{Jenis-jenis Persediaan}

Jenis persediaan yang ada dalam UD. Muda-mudi Tolitoli yaitu Barang Jadi. Barang jadi yang merupakan produk atas barang yang telah selesai diproduksi dan menjadi persediaan perusahaan untuk dijual. UD. Muda-mudi Tolitoli merupakan perusahaan yang mendistribusikan beraneka-ragam peralatan olahraga, maka persediaannya hanya satu jenis yaitu persediaan barang dagang. Persediaan barang dagangan pada UD. Muda-mudi Tolitoli meliputi barang yang di beli dan di simpan untuk dijual kembali dalam kegiatan usaha normal perusahaan.

\section{DAFTAR BARANG UD. MUDA-MUDI TOLITOLI}

\begin{tabular}{ll}
\hline Seragam Olahraga & Seragam Sepak Bola; \\
& Serangam Bulutangkis; \\
& Seragam Bola Voli; \\
& Seragam Bola Basket; \\
& Seragam Regang; \\
& Seragam Tenis Meja dan Tenis Lapangan; \\
& Seragam Bela Diri, dan \\
& Seragam Fitnes \\
\hline Sepatu Olahraga & Sepatu Mendaki, \\
& Sepatu Bolakaki, \\
& Sepatu Voli, \\
& Sepatu Basket, \\
& Sepatu Golf, \\
& Sepatu Tenis Lapangan, \\
& Sepatu Lari, dan \\
& Kaki Katak untuk Olahraga Renang \\
\hline Tas Olahraga & Tas Raket Bulutangkis, Tas Sepatu dan berbagai jenis tas untuk bermacam-macam \\
& olahraga. \\
\hline Alat-alat Olahraga & Kaca Mata Renang, \\
& Papan Pelampung, \\
& Matras, \\
& Alat Pelindung Lutut \\
& Kaos Kaki, \\
& Handuk, \\
& Senar untuk Raket Tenis Meja maupun Bulutangkis, \\
& Topi, dan \\
& Peluit \\
\hline
\end{tabular}




\section{Sistem Pencatatan Persediaan}

Sistem pencatatan persediaan yang diterapkan pada UD. Muda-mudi Tolitoli yaitu menggunakan Sistem Phisik atau Periodik. Sistem atau metode ini merupakan metode pencatatan persediaan, dimana ; Mutasi persediaan tidak menggunakan buku besar inventory melainkan memakai perkiraan pembelian, Tidak memakai kartu persediaan, dan Kalkulasi biaya persediaan dengan cara menetapkan persediaan akhir terlebih dahulu melalui perhitungan secara phisik atau periodik selanjutnya dihitung harga pokok penjualan. Menurut sistem ini setiap pembelian dan penjualan dicatat dalam perkiraan yang berbeda yaitu pembelian dan penjualan sehingga dari pencatatan akuntansi tidak dapat diketahui besarnya persediaan setiap saat. Pada umumnya sistem ini digunakan dalam perusahaan dagang seperti yang diterapkan pada UD. Muda-mudi Tolitoli.

\section{Metode Penilaian Persediaan}

UD. Muda-mudi Tolitoli menggunakan dua metode penilaian persediaan yaitu metode biaya rata-rata (average) dan metode masuk pertama keluar pertama (FIFO). Metode Biaya Rata-rata adalah metode yang membebankan biaya rata-rata yang sama kesetiap unit. Metode ini didasarkan pada asumsi bahwa barang yang terjual seharusnya dibebankan dengan biaya rata-rata tertimbang dari jumlah unit yang dibeli pada tiap harga. Metode rata-rata hanyalah mengutamakan melayani hanya yang mudah dijangkauuntuk dilayani, dan tidak begitu memperdulikan apakah barang tersebut masuk pertama atau masuk terakhir. Adapun Metode Masuk Pertama Keluar Pertama ( First in First Out) adalah metode yang mengasumsikan bahwa unit yang terjual adalah unit yang terlebih dahulu masuk. FIFO memberikan kesempatan kecil dalam memanipulasi keuntungan karena pembebanan biaya ditentukan oleh urutan terjadinya biaya. Dengan menggunakan kedua metode ini perusahaan mampu menjaga keseimbangan pemasukkan modal dalam perusahaan dan melangsungkan kehidupan perusahaan.

\subsection{Pembahasan \\ Tujuan Persediaan}

Tujuan persediaan pada UD. Tolitoli dilakukan untuk mengurangi resiko kenaikan harga, untuk mengantisipasi perubahan pada permintaan dan penawaran, menjaga persediaan bahan yang dihasilkan secara musiman, mendapat keuntungan dari quantity discount, dan lain sebagainya. Tujuan persediaan untuk UD. Muda-mudi Tolitoli dilakukan agar supaya bisa memasok barang dengan tujuan untuk mengurangi keterlabatan pengiriman barang, juga karena mengingat letak perusahaan yang berada jauh dari supplier barang.

\section{Jenis-jenis Persediaan}

UD. Muda-mudi Tolitoli merupakan perusahaan dagang, maka dari itu jenis persediaan yang ada dalam UD. Muda-mudi Tolitoli hanyalah satu jenis saja yaitu barang jadi. Persediaan barang pada UD. Muda-mudi Tolitoli meliputi barang yang dibeli dan disimpan untuk dijual kembali dalam kegiatan usaha normal perusahaaan. Berikur Daftar Barang pada UD. Muda-mudi Tolitoli. Terbagi atas empat bagian, yaitu Seragam Olahraga, Sepatu Olahraga, Tas Olahraga dan Macam-macam barang penunjang olahraga.

\section{Sistem Pencatatan Persediaan}

Sistem Pencatatan Persediaan yang di terapkan pada UD. Muda-mudi Tolitoli yaitu sistem phisik atau periodik, dimana sistem ini ;

a. Mutasi persediaan tidak menggunakan buku besar inventory melainkan menggunakan perkiraan pembelian, yang membuat sistem catatan diperusahaan ini mudah untuk terjadi penyelewengan yaitu seperti pencurian barang oleh karyawan yang tidak bertanggung 
jawab juga pencurian barang yang dilakukan oleh konsumen, sehingga menimbulkan kerugian untuk perusahaan.

b. Tidak memakai kartu persediaan, sehingga perusahaan susah memprediksi barang yang sudah terjual, hilang atau dicuri oleh pihak-pihak yang tidak bertanggung jawab.

c. Kalkulasi biaya persediaan dengan cara menetapkan persediaan akhir terlebih dahulu melalui perhitungan secara phisik atau periodik selanjutnya dihitung harga pokok.

Menurut sistem ini setiap pembelian dan penjualan dicatat dalam perkiraan yang berbeda yaitu pembelian dan penjualan sehingga dari pencatatan akuntansi tidak dapat diketahui besarnya persediaan setiap saat, penulis kurang setuju dengan sistem ini diterapkan pada perusahaan karena dengan sistem ini mudah terjadi penyelewengan atau pencurian barang. Pada umumnya sistem ini digunakan dalam perusahaan dagang. Dan inilah sistem yang diterapkan pada UD. Muda-mudi Tolitoli selama 6 bulan ketika penulis melakukan penelitian diperusahaan.

\section{Metode Penilaian Persediaan}

UD. Muda-mudi Toitoli menggunakan dua metode penilaian persediaan yatu metode biaya rata-rata (average) dan metode masuk pertama keluar pertama (first in first out). Metode FIFO atau Pertama masuk keluar pertama adalah metode yang mengasumsikan bahwa unit yang terjual adalah unit yang lebih dahulu masuk. FIFO dapat dianggap sebagai sebuah pendekatan logis dan realistis terhadap biaya juga terhadap penggunaan metode indentifikasi khusus adalah tidak memungkinkan atau tidak praktis. FIFO memberikan kesempatan kecil untuk memanipulasi keuntungan, maka dari itu UD. Muda-mudi Tolitoli menerapkan metode ini guna untuk memperoleh keuntungan. Metode FIFO digunakan oleh perusahaan karena barang dagang yang dijual berupa baju olahraga, sepatu olahraga, tas olahraga juga alat-alat olahraga merupakan barang-barang yang seiring jaman terjadi beberapa perubahan model per item barang, sehingga jika menggunakan metode FIFO perusahaan mudah memperoleh keuntungan.

Metode Biaya rata-rata adalah metode yang dibebankan sama kesetiap unit. Perusahaan menggunakan metode ini untuk menjual barang-barang yang biayanya kembali normal dari metode FIFO ke Average. Biaya rata-rata yang dijual perusahaan untuk memenuhi kebutuhan konsumen, biaya rata-rata mudah terjangkau untuk dilayani tidak peduli apakah masuk pertama atau masuk terakhir.

\section{KESIMPULAN DAN SARAN}

\subsection{Kesimpulan}

Berdasarkan hasil penelitian, dapat disimpulakan beberapa hal mengenai Penerapan

Akuntansi Persediaan Barang Dagang pada UD. Muda-mudi Tolitoli adalah sebagai berikut :

1. UD. Muda-mudi Tolitoli menggunakan Tujuan Persediaan untuk mengurangi resiko kenaikan harga, untuk mengantisipasi perubahan pada permintaan dan penawaran sudah sesuai dengan Tujuan akuntansi pada umumnya. Hal itupun sudah diterapkan pada UD. Muda-mudi Tolitoli

2. UD. Muda-mudi Tolitoli, menerapkan hanyalah mempunyai satu jenis barang yaitu barang jadi, sesuai dengan jenis perusahaan dagangan yang hanya mempunyai kegiatan seperti barang yang dibeli dan disimpan untuk dijual kembali dalam kegiatan usaha normal perusahaan.

3. UD. Muda-mudi Tolitoli menerapkan pencatatan persediaan menggunakan metode fisik atau periodic, dimana system ini disetiap pembelian dan penjualan dicatat dalam perkiraan yang berbeda yaitu pembelian dan penjualan sehingga dari pencatatan akuntansi tidak dapat diketahui besarnya persediaan setiap saat. 
4. UD. Muda-mudi Tolitoli menerapkan dua metode penilaian persediaan yaitu Metode Masuk Pertama Keluar Pertama (first in first out) dan juga Metode Rata-rata (average).

5. UD. Muda-mudi Tolitoli menerapkan Metode Masuk Pertama Keluar Pertama yaitu untuk memperoleh keuntungan karena permintaan konsumen yang selalu mengikuti trend fashion sehingga barang barulah yang banyak diminati oleh konsumen sedangkan Metode Rata-rata diterapkan karena permintaan konsumen yang memilih barang yang diminati karena factor kenyamanan pada barang tersebut.

6. UD. Muda-mudi Tolitoli menerapkan biaya persediaan yaitu Biaya Pemesanan dan Biaya Penyimpanan. Dimana Biaya Pemesanan diterapkan karena perusahaan merupakan perusahaan dagang yang menjual kembali barang yang dipesan juga terdapat Biaya Penyimpanan karena pada umumnya perusahaan dagang harus mempunyai persediaan untuk memenuhi tujuan dari perusahaan dan permintaan konsumen.

\subsection{Saran}

Sebaiknya kepada UD. Muda-mudi Tolitoli yang bermanfaat dalam mengatasi kelemahan yang terdapat dalam penerapan akuntansi persediaan persedian barang dagangan.

1. UD. Muda-mudi Tolitoli, perusahaan harus lebih fokus dalam melakukan pencatatan terhadap persediaan, juga memonitor secara berkala agar tidak terjadinya penyelewengan seperti kehilangan barang

2. UD. Muda-mudi Tolitoli, harus mengontrol kembali kinerja karyawan sesuai dengan tanggung jawab sebagaimana semestinya.

3. UD. Muda-mudi Tolitoli, kiranya bisa mengadakan cctv untuk mengontrol keadaan perusahaan agar tidak terjadi penyelewengan

4. UD. Muda-mudi Tolitoli kiranya lebih memperhatikan tentang biaya-biaya yang terjadi akibat persediaan agar bisa terkoordinir secara merata.

\section{DAFTAR PUSTAKA}

Anichabe. 2013. Effect of Inventory Management on Organisational Effectiveness. University of Nigeria, Vol.3, No.8, 2013. ISSN 2224-5758

Aprilia. 2014. Penerapan Sistem Pengendalian Intern untuk Persediaan Barang Dangangan pada CV. Multimedia Persada Manado. Universitas Samratulangi Manado Fakultas Ekonomi dan Bisnis.

Arens, A. A. 2008. Auditing dan Assurance. Ed 12. Jilid 2, Terjemahan Herman Wibowo, Jakarta: Erlangga.

Harahap, S. S. 2013. Analisis Kritis atas Laporan Keuangan. Jakarta; Raja Grafindo Persada.

Hery, 2009, Akuntansi Intermedite Illustrasi Problem dan Solusi, Edisi 1, Grasindo, Jakarta.

2014. Pengendalian Akuntansi dan Manajemen, Kencana, Jakarta 2012, Analisis Laporan Keuangan PT. Bumi Aksara. Jakarta.

Ikatan Akuntan Indonesia, 2012, Standar Akuntansi Keuangan, Penerbit Salemba Empat, Jakarta.

Indratno, A. 2013. Prinsip - Prinsip Dasar Akuntansi. Jakarta: Dunia Cerdas.

Mokoginta, O. Evaluasi Penerapan PSAK 24 (Revisi 2013) Mengenai Imbalan Kerja Pada Bank SULUTGO. Manado.

Ponto, 2013, Pengaruh Konservatisma Akuntansi, ROA dan Sales Growth terhadap sengketa pajakk penghasilan. Yapis, Papua.

Taswan, 2015, Akuntansi perbankan transaksi dalam valuta rupiah, Edisi1. Jakarta

Reeve. 2014, Pengantar Akuntansi Adaptasi Indonesia. Buku II, Jakarta.

Riahi. 2011, Teori Akuntansi edisi 5, buku I, Jakarta, Salemba empat.

Rosmeri E., Dadang., \& M. Umuh. 2016. Dasar-Dasar Akuntansi Akrual Pemerintah Daerah, Jatinangor; Ghalia Indonesia. 
Salainti. 2013. Evaluasi Penerapan Akuntansi Aset Tetap Pada PT. PLN (PERSERO) Wilayah Suluttenggo Area Manado. Manado.

Simamora. 2012, Akuntansi Manajemen. Jakarta: Star Gate Publisher.

Suwardjono, 2015, Akuntansi Pengantar, Edisi 3, Fakultas Ekonomi dan Bisnis, Universitas Gajah Madah, Jogjakarta 